\title{
THE ORIPÄ̈̈ GRANITE, SW FINLAND: CHARACTERIZATION AND SIGNIFICANCE IN TERMS OF SVECOFENNIAN CRUSTAL EVOLUTION
}

\author{
TAPANI RÄMÖ and MIKKO NIRONEN
}

\begin{abstract}
RÄMÖ, TAPANI and NIRONEN, MIKKO 2001. The Oripää granite, SW Finland: Characterization and significance in terms of Svecofennian crustal evolution. Bulletin of the Geological Society of Finland 73, Parts 1-2, 103-109.

Key words: granites, geochemistry, isotopes, neodymium, lead, crust, genesis, Proterozoic, Oripää, Finland

Tapani Rämö (corresponding author): Department of Geology, P.O. Box 64, FIN00014 University of Helsinki, Finland.E-mail: tapani.ramo@helsink.fi

Mikko Nironen: Geological Survey of Finland, P.O. Box 96, FIN-02151 Espoo, Finland
\end{abstract}

\section{INTRODUCTION}

Granitoid rocks of the Finnish Svecofennian have recently been at the focus of active research and new ideas regarding their petrogenesis and tectonic evolution have been presented by several authors (e.g., Lahtinen 1994, Lahtinen \& Huhma 1997, Elliott et al. 1998, Mäkitie 2000, Nironen et al. 2000). The Central Finland Granitoid Complex (CFGC), in particular, has been thoroughly investigated and a comprehensive picture of the source history, magmatic evolution, and tectonic significance of the Paleoproterozoic (1.89-1.87 $\mathrm{Ga}$ ) granitoids of this region is at hand.

Since the mid-1990's a collaborative project dealing with the post-kinematic $(1.88-1.87 \mathrm{Ga})$ granitoids of the CFGC has been carried out by the Geological Survey of Finland and the University of Helsinki (see Elliott et al. 1998, Nironen et al. 2000). These post-kinematic granitoids barely post-date their synkinematic granitoid hosts (Vaasjoki 1996, Rämö et al. 2001), yet they clearly intrude the synkinematic plutons and are only slightly, if at all, foliated. They also have a bimodal (silicic-mafic) magmatic association characteristic of granitoid magmatism in an extensional tectonic setting, as opposed to the convergent nature of the synkinematic magmatism (Nironen et al. 2000).

The CFGC constitutes a substantial fraction of the (accretional) arc complex of central and western Finland (see Korsman et al. 1997). One item of interest in the study of the granitoids of the CFGC has been comparison of these rocks to the granitoids of the arc complex of southern Finland (Fig. 1). Isotopic composition of the granitoids has revealed substantial regional differences within the Finnish Svecofennian that strongly suggest that the arc complexes once were exotic to each other (Lahtinen \& Huhma 1997, Rämö et al. 1999, 2001). The tectonic model of the region includes accretion of two arc prisms at $1.89 \mathrm{Ga}$ (see Nironen 1997).

Available isotopic data on the Paleoproterozo- 


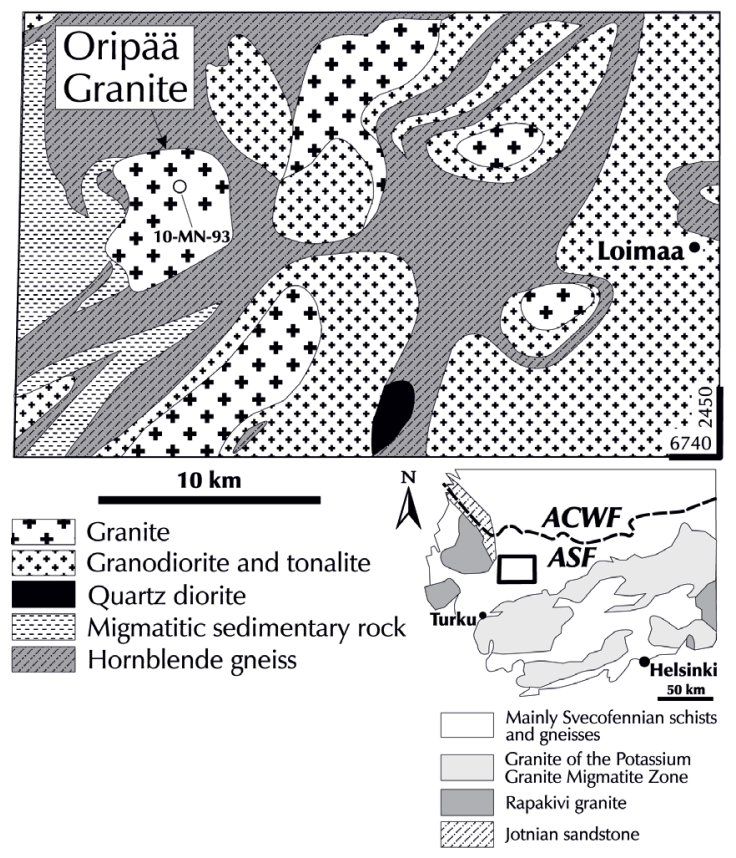

Fig. 1. Generalized geological map of the bedrock west of Loimaa, southwestern Finland and the location of the Oripää granite. Dashed line in the index map marks the boundary between the arc complex of southern Finland $(A S F)$ and the arc complex of central and western Finland (ACWF). Location of the analyzed sample is indicated. Modified from Nironen (1999).

ic granitoid rocks of the southern arc complex are rather few (Huhma 1986, Patchett \& Kouvo 1986). We have studied the Oripää granite (Nironen 1999) in the western part of the southern arc complex in order to extend the isotopic data set on the granitoids of this terrane. In this report, we present elemental geochemical and $\mathrm{Nd}$ and $\mathrm{Pb}$ isotopic data on the Oripää granite and compare these to those of the granitoids of the CFGC region farther to the north.

\section{GEOLOGICAL SETTING}

The Oripää granite is situated in the western part of the southern arc complex $\sim 60 \mathrm{~km}$ northeast of Turku (Fig. 1). It is a small $\left(\sim 20 \mathrm{~km}^{2}\right)$ stock surrounded by metamorphic rocks (migmatite, horn- blende gneiss) and is petrographically quite heterogeneous with a coarse (pegmatitic) appearance and abundant inclusions of garnet-bearing biotite gneiss and hornblende gneiss (Nironen 1999). The $\mathrm{U}-\mathrm{Pb}$ systematics of the Oripää granite are also heterogeneous with two distinct zircon populations that yielded upper intercept ages of $1850 \pm 27$ and $1860 \pm 41 \mathrm{Ma}$ (Nironen 1999). A concordant monazite has a ${ }^{207} \mathrm{~Pb} /{ }^{206} \mathrm{~Pb}$ age of $1794 \pm 10 \mathrm{Ma}$. According to Nironen (1999), the Oripää granite was emplaced during ductile $\left(\mathrm{D}_{4}\right)$ deformation preceded by a metamorphic peak at $\sim 1870 \mathrm{Ma}$, and represents dominantly in situ melt segregation.

The analyzed sample 10-MN-93 (Map Sheet 2111; Finnish National Grid coordinates $\mathrm{x}=$ 6752.200, $y=2425.840$ ) is a pink, medium-grained, quartz-rich, leucocratic biotite granite from the north-central part of the pluton (Figs. 1 and 2). It represents a rather heterogeneous medium- to coarse-grained granite with abundant xenoliths and ghost-like remnants of hornblende gneiss.

\section{ELEMENTAL GEOCHEMISTRY}

The major and trace element composition of sample 10-MN-93 was determined at the Geochemical Laboratory of the Geological Survey of Finland and is shown in Table 1 and Fig. 3. The sample is characterized by high $\mathrm{SiO}_{2}(75.3 \%)$ and $\mathrm{K}_{2} \mathrm{O}(6.9 \%)$ and low $\mathrm{Na}_{2} \mathrm{O}(2.3 \%), \mathrm{CaO}(0.31$ $\%), \mathrm{Fe}_{2} \mathrm{O}_{3}(0.43), \mathrm{MgO}(0.10)$, and $\mathrm{TiO}_{2}(0.05 \%)$. It is clearly peraluminous (Fig. 3a) and, compared to the synkinematic and post-kinematic granites of the CFGC (Nironen et al. 2000), has a low Fe/Mg relative to its high content of $\mathrm{SiO}_{2}$ (Fig. 3b).

The trace element composition of the Oripää granite is rather peculiar. $\mathrm{Ba}$ (1042 ppm), $\mathrm{Sr}$ (371 $\mathrm{ppm})$, and $\mathrm{Pb}$ (42 ppm) values are relatively high for a granite with $\sim 75 \% \mathrm{SiO}_{2}$ (cf. Fig. 6 in Nironen et al. 2000). The contents of the remainder of the analyzed trace elements are low or very low. For instance, $\mathrm{Zr}$ value is $48 \mathrm{ppm}$, La $11.5 \mathrm{ppm}$ (only $37 \mathrm{x}$ chondrite), and the contents of the four heaviest REE $(\mathrm{Er}-\mathrm{Lu})$ and $\mathrm{Nb}$ are below detection limit (Table 1). The sample is also characterized by a clearly positive Eu-anomaly $\left(\mathrm{Eu} / \mathrm{Eu}^{*}=\right.$ 


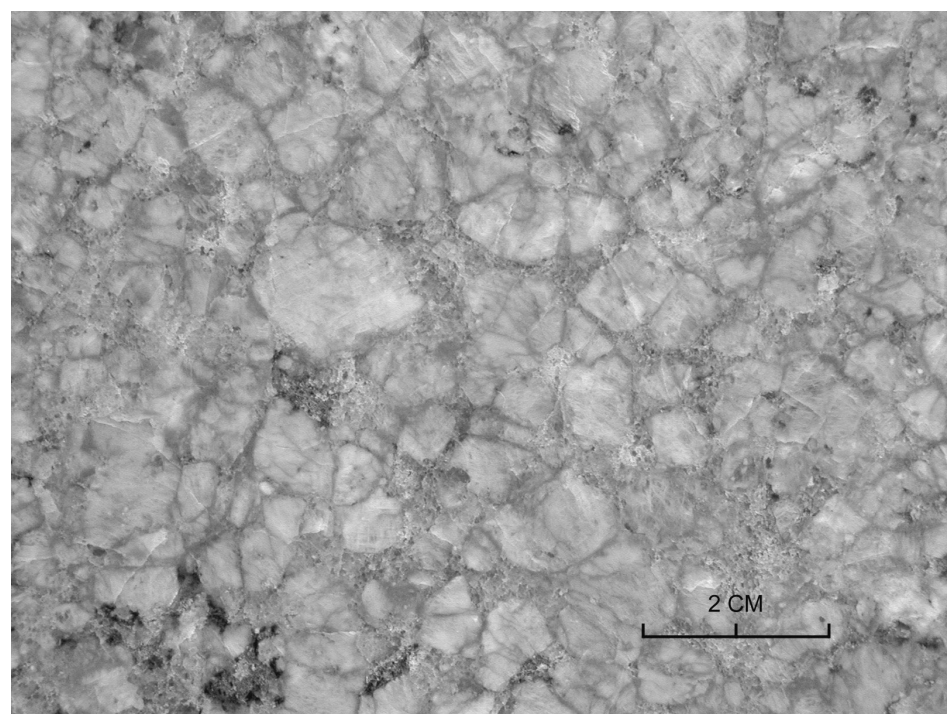

Fig. 2. Photograph of the Oripää granite, polished surface. Photo by Jari Väätäinen.
1.54). In the discrimination diagrams of Whalen et al. (1987), the Oripää granite shows the characteristics of fractionated granites (Fig. 3c).

\section{ISOTOPE GEOLOGY}

Whole-rock $\mathrm{Nd}$ and $\mathrm{Pb}$ and alkali feldspar $\mathrm{Pb}$ isotopic compositions of sample 10-MN-93 were determined by the first author at the Unit for Isotope Geology, Geological Survey of Finland ${ }^{1}$ and they are shown in Table 1 and Figs. 4 and 5. The contents of $\mathrm{Sm}$ and $\mathrm{Nd}$ are both low (1.36 and $8.85 \mathrm{ppm}$, respectively) and indicative of a strong enrichment in the light rare earth elements (light REE) with ${ }^{147} \mathrm{Sm} /{ }^{144} \mathrm{Nd}=0.09263$. The presentday ${ }^{143} \mathrm{Nd} /{ }^{144} \mathrm{Nd}$ is 0.5115 and the calculated initial $\varepsilon_{\mathrm{Nd}}$ (at $1850 \mathrm{Ma}$ ) value is clearly positive, +2.5 (Fig. 4). The depleted mantle model age is $1.94 \mathrm{Ga}$ and thus only $100 \mathrm{Ma}$ higher than the presumed crystallization age of the Oripää granite.

As can be judged from the high amount of $\mathrm{Pb}$ (42 ppm) relative to $\mathrm{U}(0.65 \mathrm{ppm})$ and $\mathrm{Th}(3.93$ ppm) of sample 10-MN-93 (Table 1), the Pb isotopic ratios of the whole-rock and alkali feldspar fractions of it are not much different from each other (Fig. 5). The Oripää alkali feldspar fraction has a $\mu_{2}$ value (present second-stage ${ }^{238} \mathrm{U} / 204 \mathrm{~Pb}$ ) of 9.67 and it plots marginally below the Stacey and Kramers (1975) model of average crustal $\mathrm{Pb}$ in the ${ }^{206} \mathrm{~Pb} /{ }^{204} \mathrm{~Pb}$ vs. ${ }^{207} \mathrm{~Pb} /{ }^{204} \mathrm{~Pb}$ diagram (Fig. 5a). Together with the whole-rock fraction, it falls on a trend corresponding to an age of $2170 \mathrm{Ma}$. Because of the quite small spread in the $\mathrm{Pb}$ isotopic ratios, however, this age has no specific significance. In the ${ }^{206} \mathrm{~Pb} / 204 \mathrm{~Pb}$ vs. ${ }^{208} \mathrm{~Pb} /{ }^{204} \mathrm{~Pb}$ diagram (Fig. 5b), the alkali feldspar - whole-rock pair indicates a relatively high long-term $\mathrm{Th} / \mathrm{U}$ of $\sim 7.4$.

\section{DISCUSSION AND CONCLUSION}

The elemental geochemical composition of the Oripää granite with its high $\mathrm{Al}$ relative to the alkalies (peraluminous nature) and low contents of mafic constituents (Fe, $\mathrm{Mg}, \mathrm{Ca}, \mathrm{Ti}$ ) imply a metasedimentary source component. This is in line with the idea of in situ melt segregation (Nironen 1999), as some of the immediate host rocks of the pluton are metasedimentary (Fig. 1). The high K/ $\mathrm{Na}, \mathrm{Ba}, \mathrm{Rb}$, and $\mathrm{Pb}$ values, low contents of REE and $\mathrm{U}$, and positive Eu anomaly show that the Oripää granite contains a major alkali feldspar 
Table 1. Elemental geochemical and $\mathrm{Nd}$ and $\mathrm{Pb}$ isotopic composition of the Oripää granite

\begin{tabular}{|c|c|}
\hline Sample name & $10-\mathrm{MN}-93$ \\
\hline $\mathrm{SiO}_{2}$ (wt.\%) & 75.34 \\
\hline $\mathrm{TiO}_{2}$ & 0.05 \\
\hline $\mathrm{Al}_{2} \mathrm{O}_{3}$ & 13.07 \\
\hline $\mathrm{Fe}_{2} \mathrm{O}_{3}$ & 0.43 \\
\hline $\mathrm{MnO}$ & 0.008 \\
\hline $\mathrm{MgO}$ & 0.10 \\
\hline $\mathrm{CaO}$ & 0.31 \\
\hline $\mathrm{Na}_{2} \mathrm{O}$ & 2.28 \\
\hline $\mathrm{K}_{2} \mathrm{O}$ & 6.92 \\
\hline $\mathrm{P}_{2} \mathrm{O}_{5}$ & 0.044 \\
\hline $\mathrm{F}$ & 0.01 \\
\hline $\mathrm{Cl}$ & 0.004 \\
\hline Total & 98.57 \\
\hline $\mathrm{A} / \mathrm{CNK}^{\mathrm{a}}$ & 1.11 \\
\hline \multicolumn{2}{|c|}{ Trace elements in ppm: } \\
\hline $\mathrm{Ga}$ & 23 \\
\hline $\mathrm{Rb}$ & 181 \\
\hline $\mathrm{Sr}$ & 371 \\
\hline $\mathrm{Ba}$ & 1042 \\
\hline $\mathrm{Nb}$ & $<1$ \\
\hline $\mathrm{Sc}$ & 0.84 \\
\hline $\mathrm{La}$ & 11.5 \\
\hline $\mathrm{Ce}$ & 21.4 \\
\hline $\operatorname{Pr}$ & 2.20 \\
\hline Eu & 0.51 \\
\hline $\mathrm{Gd}$ & 0.75 \\
\hline $\mathrm{Tb}$ & 0.11 \\
\hline Dy & 0.39 \\
\hline Но & 0.08 \\
\hline Y & 2.13 \\
\hline $\mathrm{Zr}$ & 48 \\
\hline $\mathrm{Sm}$ & 1.36 \\
\hline $\mathrm{Nd}$ & 8.85 \\
\hline${ }^{147} \mathrm{Sm} /{ }^{144} \mathrm{Nd}$ & 0.09263 \\
\hline${ }^{143} \mathrm{Nd} /{ }^{144} \mathrm{Nd}^{\mathrm{b}}$ & $0.511500 \pm 0.000016$ \\
\hline$\varepsilon_{\mathrm{Nd} i}(1850 \mathrm{Ma})^{\mathrm{c}}$ & +2.5 \\
\hline $\mathrm{T}_{\mathrm{DM}}(\mathrm{Ga})^{\mathrm{d}}$ & 1.94 \\
\hline $\mathrm{Pb}$ & 42 \\
\hline Th & 3.93 \\
\hline $\mathrm{U}$ & 0.65 \\
\hline${ }^{206} \mathrm{~Pb} /{ }^{204} \mathrm{~Pb}^{\mathrm{b}}$ & 16.310 \\
\hline${ }^{207} \mathrm{~Pb} / 204 \mathrm{~Pb}^{\mathrm{b}}$ & 15.392 \\
\hline${ }^{208} \mathrm{~Pb} / 204 \mathrm{~Pb}^{\mathrm{b}}$ & 36.184 \\
\hline${ }^{206} \mathrm{~Pb} / 204 \mathrm{~Pb}_{i}{ }^{\mathrm{e}}$ & 15.875 \\
\hline${ }^{207} \mathrm{~Pb} / 204 \mathrm{~Pb}_{i}{ }^{\mathrm{e}}$ & 15.333 \\
\hline${ }^{208} \mathrm{~Pb} / 204 \mathrm{~Pb}_{i}{ }^{\mathrm{e}}$ & 35.272 \\
\hline
\end{tabular}
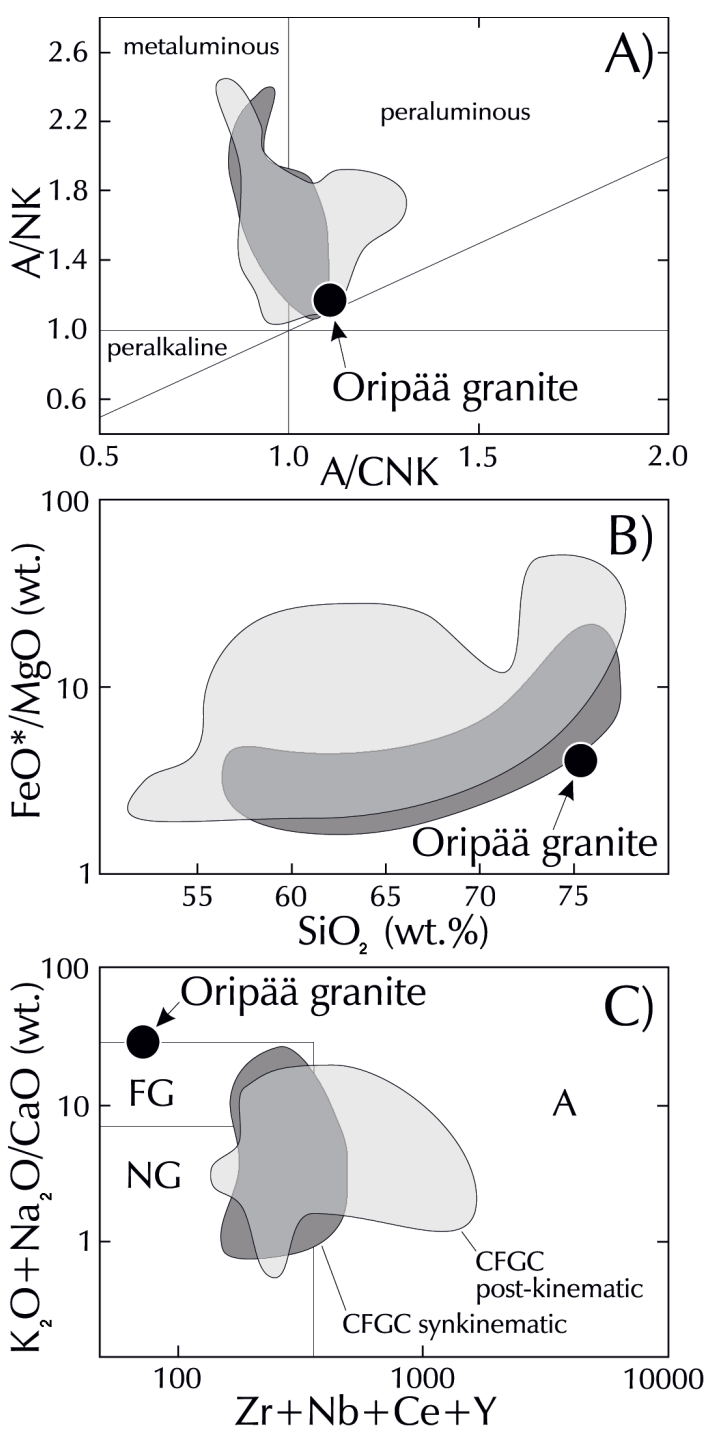

Fig. 3. Chemical composition of the Oripää granite shown in (a) A/CNK (molecular $\mathrm{Al}_{2} \mathrm{O}_{3} /\left[\mathrm{CaO}+\mathrm{Na}_{2} \mathrm{O}+\right.$ $\left.\mathrm{K}_{2} \mathrm{O}\right]$ ) vs. A/NK (molecular $\mathrm{Al}_{2} \mathrm{O}_{3} /\left[\mathrm{Na}_{2} \mathrm{O}+\mathrm{K}_{2} \mathrm{O}\right]$ ), (b) $\mathrm{FeO} * / \mathrm{MgO}$ vs. $\mathrm{SiO}_{2}$, and (c) $\left(\mathrm{K}_{2} \mathrm{O}+\mathrm{Na}_{2} \mathrm{O}\right) / \mathrm{CaO}$ vs. $\mathrm{Zr}$ $+\mathrm{Nb}+\mathrm{Ce}+\mathrm{Y}$ diagrams. Fields for the syn-and postkinematic granitoids of the CFGC (Nironen et al. 2000) are also shown. $\mathrm{FeO}$ * denotes total iron. Fields labeled A (A-type granite), FG (fractionated $M-$, I-, and S-type granite), and $N G$ (unfractionated $M-, I-$, and S-type granite) in (c) are after Whalen et al. (1987).

Note: Analyses at the Geological Survey of Finland (GTK). Major oxides, Ga, Rb, Sr, Ba, Nb, Zr, an Pb by XRF; Sm and Nd by ID/MS; all other trace elements by ICP/MS.

a $\mathrm{Al}_{2} \mathrm{O}_{3} /\left(\mathrm{CaO}+\mathrm{Na}_{2} \mathrm{O}+\mathrm{K}_{2} \mathrm{O}\right)$, molecular

b ${ }^{143} \mathrm{Nd} /{ }^{144} \mathrm{Nd}$ normalized to ${ }^{146} \mathrm{Nd} /{ }^{144} \mathrm{Nd}=0.7219$; reported error is $2 \sigma_{\mathrm{m}}$. Pb isotopic ratios reported relative to the $\mathrm{NBS} 981$ standard.

${ }^{\mathrm{c}}$ Initial $\varepsilon_{\mathrm{Nd}}$ value, calculated using chondritic values of ${ }^{143} \mathrm{Nd} /{ }^{144} \mathrm{Nd}=0.51264$ and ${ }^{147} \mathrm{Sm} /{ }^{144} \mathrm{Nd}=0.1966$.

d Depleted mantle model age (DePaolo 1981).

e Measured on alkali feldspar fraction. 


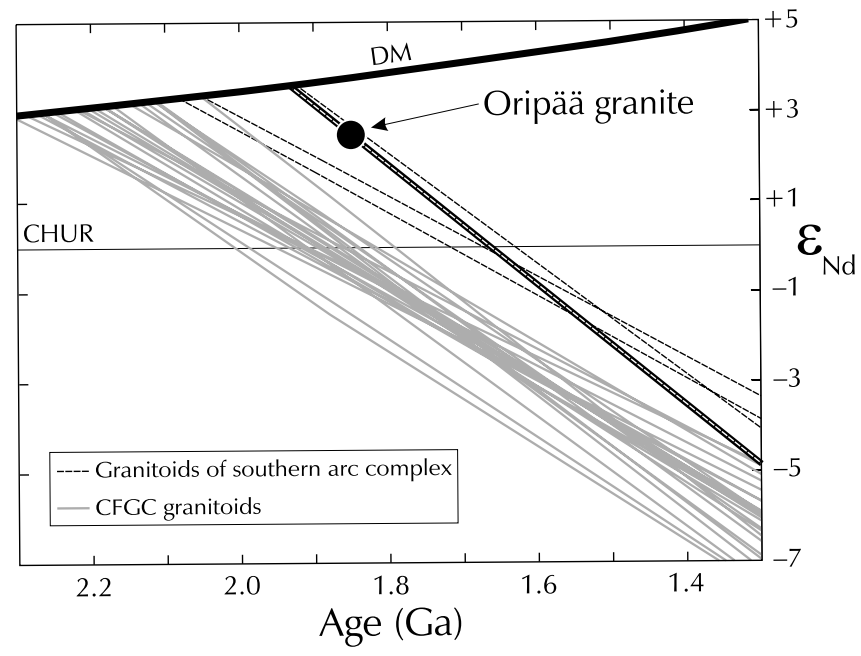

Fig. 4. $\varepsilon_{N d}$ vs. age diagram showing the initial Nd isotopic composition of the Oripää granite (Table 1) and evolution lines (Huhma 1986, Patchett \& Kouvo 1986, Rämö et al. 2001) for Paleoproterozoic granitoids of the arc complex of southern Finland (dashed) and the syn- and post-kinematic granitoids of the Central Finland Granitoid Complex $(C F G C)$, representing the arc complex of central and western Finland (gray). Also shown is the evolution of depleted mantle (DM; DePaolo 1981) and undifferentiated Earth (CHUR; DePaolo \& Wasserburg 1976). component. This is consistent with the cumulate nature of the rock (abundant subhedral/euhedral K-feldspar; Fig. 2). Moreover, the low $\mathrm{Zr}$ content together with the overall pegmatitic nature of the granite implies relatively low-temperature melting.

In Fig. 5, the $\mathrm{Pb}$ isotopic composition of the Oripää granite is compared to that of the post-kinematic granitoids of the CFGC. The latter were presumably derived from a mafic metaigneous source (Nironen et al. 2000, Elliott submitted) and have lower $\mu_{2}$ values than the Oripää granite. The relatively high- $\mu$ character of the Oripää granite is quite compatible with the presumed sedimentary source, as this feature can be ascribed to an upper crustal provenance with high overall $\mathrm{U} / \mathrm{Pb}$ (see e.g. Zartman \& Haines 1988). It is possible that the Oripää granite is an extension of the Potassium Granite Migmatite Zone (Fig. 1); in the absence of ample data on the migmatite granites, however, this cannot be verified at this point. The younger zircon population of Oripää (Nironen 1999) may be related to melting during thrusting that followed the accretion of the southern arc complex to the northern one (cf. Lahtinen 1994, Nironen 1997).

The Oripää granite differs from the post-kinematic granites of the CFGC also in terms of thorogenic $\mathrm{Pb}$. The ${ }^{208} \mathrm{~Pb} /{ }^{204} \mathrm{~Pb}$ of Oripää is clearly higher than those of the post-kinematic granitoids with $\sim$ similar ${ }^{206} \mathrm{~Pb} / 204 \mathrm{~Pb}$ (Fig. 5b), and, therefore, the calculated long-term $\mathrm{Th} / \mathrm{U}$ is higher ( 7.4 as opposed to $\sim 2$; Rämö et al. 2001). Because both zircon and monazite were probably retained in the source during the low-temperature melting, the high $\mathrm{Th} / \mathrm{U}$ is considered to point to a mature sedimentary source component that had been impoverished in $\mathrm{U}$ relative to $\mathrm{Th}$ in an oxidizing (surface) environment.

In view of the metasedimentary nature of the Oripää granite and its presumed source rock, the radiogenic initial $\mathrm{Nd}$ isotopic composition, $\varepsilon_{\mathrm{Nd}}$ (at $1850 \mathrm{Ma}$ ) of +2.5 (Fig. 4), is quite remarkable. It shows that the sedimentary detritus that contributed to the source of Oripää was relatively juvenile in character. Compared to the composition of the granitoids of the CFGC (gray evolution lines in Fig. 4), the Oripää granite is clearly more juvenile. This indicates that CFGC-type crust did not significantly contribute to the protolith of the Oripää granite. The more radiogenic $\mathrm{Nd}$ isotopic composition of the Oripää granite is, however, rather similar to those of other granitoid rocks analyzed from the arc complex of southern Finland (Figs. 1 and 4). These two crustal domains the arc complex of southern Finland and the arc complex of central and western Finland (the CFGC region) - have been proposed to constitute distinct Paleoproterozoic terranes with different incipient evolution and age (e.g., Lahtinen \& Huhma 1997, Rämö et al. 1999, 2001). Our data on 


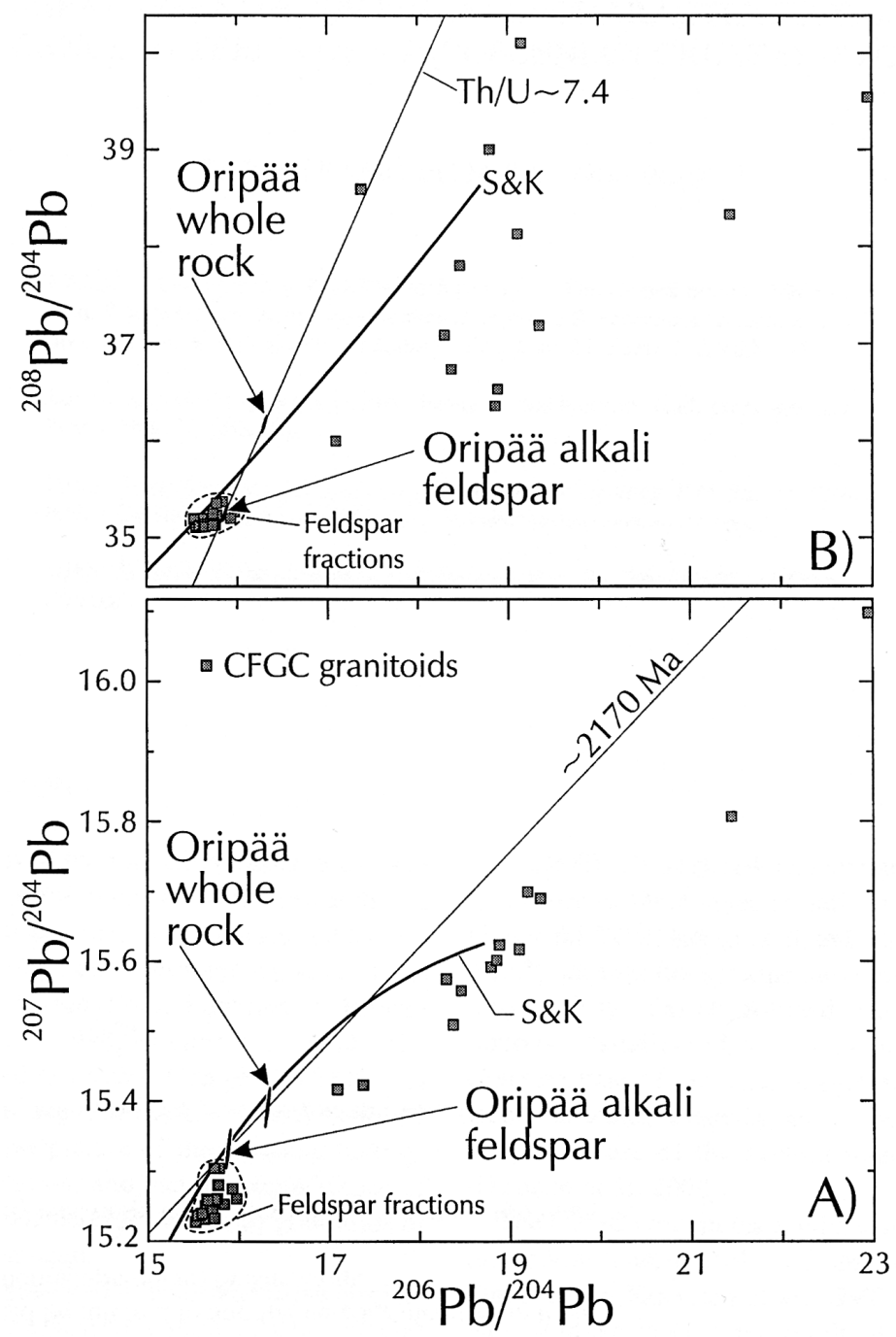

Fig. 5. (a) ${ }^{206} \mathrm{~Pb} /{ }^{204} \mathrm{~Pb}$ vs. ${ }^{207} \mathrm{~Pb} / 204 \mathrm{~Pb}$ and (b) ${ }^{206} \mathrm{~Pb} /{ }^{204} \mathrm{~Pb}$ vs. ${ }^{208} \mathrm{~Pb} /{ }^{204} \mathrm{~Pb}$ diagrams showing the $\mathrm{Pb}$ isotopic composition of whole-rock and alkali feldspar fractions of the Oripää granite (Table 1) and the Paleoproterozoic granitoids of the arc complex of western and central Finland (the CFGC region; Rämö et al. 2001). $S \& K$ is the growth curve for average crustal Pb (Stacey \& Kramers 1975). Symbol size of the Oripää samples is proportional to the $2 \sigma$ error in the variables. the Oripää granite do indeed allow the hypothesis that the southern terrane had a somewhat younger nucleus than the northern one that includes the CFGC region. It should be emphasized, however, that available isotopic data on the Svecofennian granitoids of the southern arc complex are few and more data on granitoid rocks with a clear metasedimentary source component are needed for a comprehensive assessment of the origin of the southern terrane.

ACKNOWLEDGMENTS. The first author's thanks go to the staff of the Unit for Isotope Geology, Geological Survey of Finland for help while making the isotope analyses. Discussions with Han- nи Huhma, Matti Vaasjoki, and Irmeli Mänttäri were fruitful. Raimo Lahtinen (Espoo) and Dmitry Konopelko (St. Petersburg) provided helpful reviews of the manuscript. Editorial comments by Yrjö Kähkönen are acknowledged. Supported by the Academy of Finland (projects 36002 and 44145). Contribution to IGCP Project 426 "Granite Systems and Proterozoic Lithospheric Processes".

\section{REFERENCES}

DePaolo, D.J. 1981. Neodymium isotopes in the Colorado Front Range and crust-mantle evolution in the Proterozoic. Nature 291, 193-196. 
DePaolo, D.J. \& Wasserburg, G.J. 1976. Nd isotopic variations and petrogenetic models. Geophysical Research Letters 3, 249-252.

Elliott, B.A. submitted. Petrogenesis of the post-kinematic magmatism of the Central Finland Granitoid Complex II; Protolith characteristics and magmatic evolution. Manuscript submitted to the Journal of Petrology.

Elliott, B., Rämö, O.T. \& Nironen, M. 1998. Mineral chemistry constraints on the evolution of the $1.88-1.87 \mathrm{Ga}$ post-kinematic granite plutons in the Central Finland Granitoid Complex. Lithos 45, 109-129.

Huhma, H. 1986. Sm-Nd, U-Pb and $\mathrm{Pb}-\mathrm{Pb}$ isotopic evidence for the origin of the early Proterozoic Svecokarelian crust in Finland. Geological Survey of Finland, Bulletin 337.52 p.

Korsman, K., Koistinen, T., Kohonen, J., Wennerström, M., Ekdahl, E., Honkamo, M., Idman, H. \& Pekkala, Y. (eds.) 1997. Suomen kallioperäkartta - Berggrundskarta över Finland - Bedrock map of Finland. 1: 1000000. Geological Survey of Finland, Espoo.

Korsman, K., Korja, T. Pajunen, M., Virransalo, P. \& GGT/ SVEKA Working Group 1999. The GGT/SVEKA Transect: Structure and evolution of the continental crust in the Paleoproterozoic Svecofennian orogen in Finland. International Geology Review 41, 287-333.

Lahtinen, R. 1994. Crustal evolution of the Svecofennian and Karelian domains during 2.1-1.79 Ga, with special emphasis on the geochemistry and origin of 1.93-1.91 Ga gneissic tonalites and associated supracrustal rocks in the Rautalampi area, central Finland. Geological Survey of Finland, Bulletin 378. 128 p.

Lahtinen, R. \& Huhma, H. 1997. Isotopic and geochemical constraints on the evolution of the 1.93-1.79 Ga Svecofennian crust and mantle in Finland. Precambrian Research 82, 13-34.

Mäkitie, H. 2000. Granitoids (1.89-1.87 Ga), diatexites (1.89-1.88 Ga) and granitic pegmatites (1.80-1.79 Ga), and structural-metamorphic evolution in the Seinäjoki region, western Finland. Academic dissertation. Geolog- ical Survey of Finland, Espoo. 35 pages with 5 original papers.

Nironen, M. 1999. Structural and magmatic evolution in the Loimaa area, southwestern Finland. Bulletin of the Geological Society of Finland 71, 57-71.

Nironen, M., Elliott, B. \& Rämö, O.T. 2000. 1.88-1.87 Ga post-kinematic intrusions of Central Finland Granitoid Complex: a shift from C-type to A-type magmatism during lithospheric convergence. Lithos 53, 37-58.

Patchett, J. \& Kouvo, O. 1986. Origin of continental crust of 1.9-1.7 Ga age: $\mathrm{Nd}$ isotopes and $\mathrm{U}-\mathrm{Pb}$ zircon ages in the Svecokarelian terrain of south Finland. Contributions to Mineralogy and Petrology 92, 1-12.

Rämö, O.T, Nironen, M., Kosunen, P. \& Elliott, B.A. 1999. Proterozoic granites of south-central Finland - traverse across a Paleoproterozoic terrane boundary, field trip to southern and central Finland, September 13-18, 1999. Helsinki University Press. 106 p.

Rämö, O.T., Vaasjoki, M., Mänttäri, I., Elliott, B.A. \& Nironen, M. 2001. Petrogenesis of the post-kinematic magmatism of the Central Finland Granitoid Complex I; Radiogenic isotope constraints and implications for crustal evolution. Journal of Petrology 42, 1971-1993.

Stacey, J.S. \& Kramers, J.D. 1975. Approximation of terrestrial lead isotope evolution by a two-stage model. Earth and Planetary Science Letters 26, 207-221.

Vaasjoki, M. 1996. Explanation to the geochronological map of southern Finland: The development of continental crust with special reference to the Svecofennian orogeny. Geological Survey of Finland, Report of Investigation $135.30 \mathrm{p}$.

Whalen, J.B., Currie, K.L. \& Chappell, B.W. 1987. A-type granites; Geochemical characteristics, discrimination, and petrogenesis. Contributions to Mineralogy and Petrology 95, 407-419.

Zartman, R.E. \& Haines, S.M. 1988. The plumbotectonic model for $\mathrm{Pb}$ isotopic systematics among major terrestrial reservoirs - A case for bi-directional transport. Geochimica et Cosmochimica Acta 52, 1327-1339. 